\title{
Tytus Jaskułowski, Przyjaźń, której nie było. Ministerstwo Bezpieczeństwa Państwowego NRD wobec MSW 1974-1990
}

Wydawnictwa Uniwersytetu Warszawskiego, Warszawa 2014, ss. 487.

Autorem recenzowanej monografii jest dobrze znany $\mathrm{w}$ środowisku naukowym w Polsce i Niemczech politolog, Tytus Jaskułowski. Jest on pracownikiem naukowym w Instytucie Badań nad Totalitaryzmem im. Hannah Arendt na Uniwersytecie Technicznym w Dreźnie. Studiował na Uniwersytecie Gdańskim, Politechnice Gdańskiej oraz Wolnym Uniwersytecie w Berlinie. Pracował w Polskim Instytucie Spraw Międzynarodowych oraz Osteuropa-Zentrum w Berlinie. Jest autorem m.in. kilku ciekawych i wartościowych monografii dotyczących Niemieckiej Republiki Demokratycznej ${ }^{1}$. Specjalizuje się w dziejach NRD oraz najnowszej historii stosunków polsko-niemieckich. Recenzowana książka, która stanowi rezultat przygotowywanej przez autora habilitacji, została opublikowana na początku 2014 roku przez Wydawnictwa Uniwersytetu Warszawskiego. Należy dodać, że kilka miesięcy później Tytus Jaskułowski został laureatem siódmej edycji konkursu „Książka Historyczna Roku”, otrzymując Nagrodę im. Oskara Haleckiego. Jego

\footnotetext{
1 Na łamach „Rocznika Polsko-Niemieckiego” ukazały się recenzje z następujących książek Tytusa Jaskułowskiego: Pokojowa rewolucja w Niemieckiej Republice Demokratycznej w latach 1989-1990. Geneza - przebieg - efekty (2008, nr 16); Ostatnie miesiace NRD (2011, nr 19) oraz prac zbiorowych pod jego redakcją: Pokojowa rewolucja w NRD w prasie polskiej 1989-1990 (Wybór źródeł) [2008, nr 16]; Dwadzieścia lat później. Rozmowy o polsko-niemieckim traktacie o dobrym sąsiedztwie i przyjaznej wspótpracy $(2012, \mathrm{nr} 20)$.
} 
monografia została nagrodzona w kategorii „Najlepsza książka naukowa poświęcona dziejom Polski i Polaków w XX wieku”².

Oficjalnie Polska Rzeczpospolita Ludowa (PRL) oraz Niemiecka Republika Demokratyczna (NRD) były dla siebie bratnimi krajami socjalistycznymi, sojusznikiem w Układzie Warszawskim oraz partnerem w Radzie Wzajemnej Pomocy Gospodarczej. W istocie stosunki między obu krajami były niezbyt dobre, a czasem wręcz złe z powodu sprzecznych interesów. Przede wszystkim państwa te konkurowały ze sobą o względy ZSRR i pierwszą pozycję po nim w Układzie Warszawskim. Oba kraje potrzebowały wsparcia finansowego i zabiegały o nie (kredyty) w RFN. Ponadto do roku 1989 istniał między nimi konflikt graniczny na Zatoce Pomorskiej. Oprócz tego po przesileniu politycznym w 1980 roku NRD koniecznie domagała się interwencji zbrojnej w PRL. Istniało o wiele więcej sprzecznych interesów obu krajów, co nie przyczyniało się do prawdziwej bratniej przyjaźni między nimi. Wszystko to miało wpływ na kontakty i współpracę służb bezpieczeństwa obu państw, chociaż oficjalnie określano te stosunki jako przyjazne lub też często odmieniano słowo „przyjaźń". W sposób nowatorski autor monografii przedstawia nam wzajemne relacje wschodnioniemieckich i PRL-owskich resortów bezpieczeństwa - nie tylko ich współpracę, ale przede wszystkim rywalizację miedzy nimi. Dotychczas w literaturze naukowej oraz publicystyce można było się spotkać z wieloma, powielanymi przez lata, mitami dotyczącymi działalności polskiego Ministerstwa Spraw Wewnętrznych (MSW) i Stasi. Jaskułowski podważa dotychczasowe tezy i stereotypy. Obala przede wszystkim trzy podstawowe mity. Pierwszy mit dotyczył domniemanej siły służb bezpieczeństwa NRD (Stasi) na terenie Polski, która prowadziła działania przeciwko polskim władzom i polskiej opozycji - penetrowała wiele obszarów życia politycznego kraju i w pewnym stopniu wpływała na jego kształt. Przypuszczano, że Stasi posiadała nawet do 1500 swoich agentów w Polsce. Drugi mit głosił, że polskie MSW było znacznie słabsze niż jego wschodnioniemiecki odpowiednik i nie prowadziło działalności przeciwko NRD i Stasi. Z kolei trzeci mit dotyczył współ-

2 Ksiażka historyczna roku po raz siódmy!, http://www.ksiazkahistorycznaroku.pl/ [dostęp: 20 grudnia 2014]. 
pracy między obiema bezpiekami. Przez lata powielano tezę, że obie służby miały wspólne interesy i z tego powodu istniała między nimi rozwinięta kooperacja. Autor obala te mity na podstawie materiałów zebranych podczas pięcioletniej kwerendy archiwalnej w Instytucie Pamięci Narodowej oraz niemieckim Urzędzie Federalnego Pełnomocnika ds. Akt Służby Bezpieczeństwa NRD, potocznie nazywanym „urzędem Gaucka", i przeprowadzonej wnikliwej, starannej analizie porównawczej akt obu służb bezpieczeństwa, a także przeprowadzonym rozmowom z byłymi tajnymi współpracownikami, kadrowymi oficerami MSW i innymi świadkami opisywanych w książce wydarzeń, szczególnie $\mathrm{z}$ ofiarami działalności ministerstw. Ukazuje on czytelnikom nieznane dotychczas fakty współpracy między bezpiekami obu krajów, $\mathrm{w}$ tym przede wszystkim rodzaje działań polskiego MSW skierowane przeciwko NRD, aktywność podwójnych agentów itp. Udowadnia, że obydwie służby bezpieczeństwa prowadziły wobec siebie działania ofensywne, nie tylko konkurowały, ale też walczyły ze sobą. Wiele miejsca poświęca działalności ofensywnej polskich służb prowadzonej w sąsiedniej „bratniej” NRD. Tym samym dowodzi, że pomiędzy służbami bezpieczeństwa PRL i NRD nie istniała przyjaźń. Natomiast współpraca między nimi była tylko pozorna. W rzeczywistości istniała na niewielką skalę. Niechętnie wymieniano się informacjami. Jeżeli już taka kooperacja istniała, to zazwyczaj tam, gdzie dana służba bezpieczeństwa nie była $\mathrm{w}$ stanie przeprowadzić operacji samodzielnie. Współpraca podejmowana przez NRD z Polską i odwrotnie bardziej służyła ochronie i realizacji własnych interesów służb niż interesom dwustronnym. Podejmowano zazwyczaj współpracę głównie po to, aby chronić interesy własne, a nie „bratniego” kraju.

Cezury książki wyznaczają przede wszystkim lata 1974-1989. Autor wybrał celowo ten okres, ponieważ są to lata obowiązywania zawartego kompleksowego porozumienia dotyczącego współpracy między służbami bezpieczeństwa NRD i PRL. W 1974 roku obydwa resorty podpisały umowę o kooperacji. Celem książki jest dogłębna analiza, a zarazem ukazanie prawdziwych relacji między służbami bezpieczeństwa PRL i NRD. Jaskułowskiego interesuje poznanie mechanizmów wzajemnych relacji służb oraz przyczyn i skutków tych relacji. Książka wykorzystuje 
niezwykle bogatą bazę źródłowa, nie tylko niemiecko- i polskojęzyczną literaturę przedmiotu i publikacje prasowe, ale w szczególności, co jest wielkim atutem monografii, niepublikowane dotąd polskie oraz niemieckie źródła archiwalne. Monografia składa się ze wstępu, pięciu rozdziałów i zakończenia. Dodatkowo została opatrzona indeksem osobowym oraz wykazem źródeł i skrótów.

Rozdział pierwszy autor poświęcił rozważaniom teoretycznym dotyczącym współpracy tajnych służb. Przeanalizował pojęcie współpracy, zwłaszcza pod kątem teorii służb specjalnych. Dokonał porównania polskiego MSW z Ministerstwem Bezpieczeństwa Państwowego (MfS) NRD, a co ciekawe, mimo że formalnie chronologia książki rozpoczyna się w 1974 roku, to autor ukazał relacje i różnice w działaniu resortów bezpieczeństwa NRD i PRL od 1949 roku.

$\mathrm{W}$ rozdziale drugim autor opisał podstawy prawne relacji między oboma resortami, ukazał kontakty przedstawicieli enerdowskiego MfS i polskiego MSW na szczeblu kierowniczym, które stanowiły podłoże ciągłych konfliktów na poziomie partyjnym i dyplomatycznym między polskimi i wschodnioniemieckimi władzami państwowymi. Ponadto $\mathrm{w}$ tym rozdziale zostały przedstawione dyrektywy kierownictwa enerdowskiego ministerstwa odnośnie do polityki wobec PRL.

W kolejnym rozdziale Jaskułowski zajął się wnikliwym opisem współpracy wywiadowczej i kontrwywiadowczej obu służb bezpieczeństwa oraz wymiany raportów politycznych między oboma służbami i ich kooperacji w zakresie techniki specjalnej i radiokontrwywiadu. Zwrócił szczególną uwagę na skalę prowadzonej współpracy na tle zadań realizowanych przez dany resort samodzielnie lub wspólnie z innymi służbami specjalnymi państw socjalistycznych.

Rozdział czwarty został poświęcony problematyce zagrożeń wewnętrznych i zewnętrznych, przed jakimi stawały obie tajne służby. Dotyczyły one zwłaszcza kwestii opozycji antysystemowej, Kościołów i związków wyznaniowych, inwigilacji obywateli, ochrony i kontroli granicy państwowej, kontroli gospodarek narodowych. Autor ukazał, jak w rzeczywistości wyglądała (ewentualnie na czym miała polegać) współpraca $\mathrm{w}$ tym zakresie między oboma służbami bezpieczeństwa. 
W ostatnim, piątym, rozdziale swojej monografii autor przedstawił czytelnikowi nieznane wcześniej działania ofensywne przeciwko PRL i obronę przed nimi w Polsce i poza jej granicami. Ponadto podjął się przedstawienia kwestii działalności agentury oraz postrzegania kraju sąsiadniego z punktu widzenia obu państwowych resortów, która miała wpływ na wzajemną współpracę „bratnich” krajów, a tym samym obu służb specjalnych PRL i NRD.

Mimo bogatego aparatu naukowego i trudnego tematu książka jest napisana przystępnie i czyta się ją z dużym zainteresowaniem. Każdy rozdział, a w nim podrozdziały, stanowią logiczną całość i jeden po drugim wprowadzają czytelnika w tajniki działalności obu służb bezpieczeństwa, odkrywając nowe fakty i mechanizmy ich funkcjonowania. Recenzowana praca jest ciekawa i wnosi do literatury przedmiotu nowe spojrzenie na podjętą tematykę. Książka bez wątpienia zasługuje na uwagę, a autor na uznanie. Zachęcam do jej lektury wszystkich, zwłaszcza tych, którzy chcą się dowiedzieć o działalności tajnych służb w PRL i NRD, ich rzeczywistej współpracy oraz interesują się historią wzajemnych kontaktów obu krajów. 